\title{
STIM Proteins and Glutamate Receptors in Neurons: Role in Neuronal Physiology and Neurodegenerative Diseases
}

\author{
Karolina Serwach and Joanna Gruszczynska-Biegala * D \\ Molecular Biology Unit, Mossakowski Medical Research Centre, Polish Academy of Sciences, 5 Pawińskiego Str., \\ 02-106 Warsaw, Poland; kserwach@imdik.pan.pl \\ * Correspondence: jgruszczynska@imdik.pan.pl
}

Received: 14 March 2019; Accepted: 30 April 2019; Published: 9 May 2019

check for updates

\begin{abstract}
Neuronal calcium $\left(\mathrm{Ca}^{2+}\right)$ influx has long been ascribed mainly to voltage-gated $\mathrm{Ca}^{2+}$ channels and glutamate receptor channels. Recent research has shown that it is also complemented by stromal interaction molecule (STIM) protein-mediated store-operated $\mathrm{Ca}^{2+}$ entry (SOCE). SOCE is described as $\mathrm{Ca}^{2+}$ flow into cells in response to the depletion of endoplasmic reticulum $\mathrm{Ca}^{2+}$ stores. The present review summarizes recent studies that indicate a relationship between neuronal SOCE that is mediated by STIM1 and STIM2 proteins and glutamate receptors under both physiological and pathological conditions, such as neurodegenerative disorders. We present evidence that the dysregulation of neuronal SOCE and glutamate receptor activity are hallmarks of acute neurodegenerative diseases (e.g., traumatic brain injury and cerebral ischemia) and chronic neurodegenerative diseases (e.g., Alzheimer's disease and Huntington's disease). Emerging evidence indicates a role for STIM proteins and glutamate receptors in neuronal physiology and pathology, making them potential therapeutic targets.
\end{abstract}

Keywords: STIM; glutamate receptors; SOCE; synaptic plasticity; neurodegenerative diseases

\section{Introduction}

L-Glutamate is the most abundant neurotransmitter in the mammalian central nervous system (CNS) that mediates excitatory synaptic transmission [1]. It interacts with both ionotropic and metabotropic receptors, which belong to the group of glutamate receptors. Ionotropic receptors are ligand-gated ion channels that include $\alpha$-amino-3-hydroxy-5-methyl-4-isoxazolepropionic acid receptors (AMPARs), N-methyl-D-aspartate receptors (NMDARs), and kainate receptors. Among all of the glutamate receptors, AMPARs, which consist of four subunits (GluA1-4), are considered the most significant mediators of excitatory neurotransmission in the CNS [2]. NMDARs, composed of three subunits (NR1-3), are involved in various processes, from learning and memory to neurodegeneration [3]. A single NMDAR is generally considered to consist of two glycine-binding NR1 subunits and two glutamate-binding NR2 subunits and is responsible for synaptic transmission and plasticity. Metabotropic glutamate receptors (mGluRs), which are classified into three groups (I, II, and III), have a widespread distribution in the CNS and play a pivotal role in synaptic transmission and activity-dependent synaptic plasticity. The main role in synaptic plasticity is assigned to group I mGluRs (mGluR1 and mGluR5) [4]. The binding of glutamate to group I mGluRs activates two main signaling pathways [5]. In the first pathway, group I mGluRs couple to G $\alpha$-protein, which activates phospholipase $\mathrm{C}$ (PLC), thus inducing the formation of inositol trisphosphate $\left(\mathrm{IP}_{3}\right) . \mathrm{IP}_{3}$ interacts with the $\mathrm{IP}_{3}$ receptor $\left(\mathrm{IP}_{3} \mathrm{R}\right)$, causing the release of $\mathrm{Ca}^{2+}$ from endoplasmic reticulum (ER) stores [5]. The second pathway is associated with the formation of slow excitatory postsynaptic potentials [6] and is mediated by $\mathrm{G} \alpha$-protein and transient receptor potential channel 3 (TRPC3) [7]. 
The stimulation of glutamate receptors plays a pivotal role in the formation of basal excitatory synaptic transmission and different forms of synaptic plasticity, such as long-term potentiation (LTP) and long-term depression (LTD). Both LTP and LTD are fundamental neuronal mechanisms that underlie learning and memory [8] and rely mainly on NMDAR activation. mGluRs have also been implicated in LTP and LTD, but the mechanism of this involvement is much more elusive $[9,10]$. NMDA-mediated LTP is described as enhancement of the synaptic response to baseline stimuli that occurs primarily as a result of cooperation between AMPARs and NMDARs. Synaptic activity initially stimulates the influx of sodium ions $\left(\mathrm{Na}^{+}\right)$through AMPAR channels. The flow of $\mathrm{Na}^{+}$enhances the concentration of positively charged ions in the cytoplasm, causing cell depolarization. Consequently, NMDAR channels become permeable to calcium ions $\left(\mathrm{Ca}^{2+}\right)$, and $\mathrm{Ca}^{2+}$ influx induces a cascade of plastic changes. In the initial stages of LTP (i.e., early LTP [E-LTP]), it activates $\mathrm{Ca}^{2+} /$ calmodulin-dependent protein kinase II (CaMKII), protein kinase $\mathrm{C}$ (PKC), protein kinase $\mathrm{A}$ (PKA), and tyrosine kinase, which then phosphorylate AMPARs and NMDARs. The AMPA channel properties and activity-dependent synaptic delivery are regulated by phosphorylation at the Ser-831 and Ser-845 sites of the C-terminal cytoplasmic tail of GluA1 [11]. The first site is phosphorylated by CaMKII and PKC, which modulate the single-channel conductance of AMPARs [12]. The second site is phosphorylated by cyclic adenosine monophosphate (cAMP)-dependent PKA, which promotes the surface delivery of AMPARs [13] and increases the probability of receptor channel opening [14]. The transport of AMPARs to the synaptic site requires AMPARs-containing vesicles/endosomes and SNARE-proteins that mediate the fusion of vesicles/endosomes with the PM. Firstly, the receptors are inserted into the PM in the soma or dendrites at extrasynaptic sites and then they travel to dendritic spines [15]. NMDARs are phosphorylated by tyrosine kinase (which increases the open time of the channels) and PKC (which enhances the probability of channel opening and reduces their affinity to magnesium ions) [16]. Late LTP (L-LTP) is induced by changes in gene expression and by the synthesis of proteins that sustain LTP. These proteins contribute to increases in the number and surface area of dendritic spines and their postsynaptic sensitivity to neurotransmitters. The latter may also be associated with an increase in AMPAR synthesis [17].

Synaptic plasticity in the hippocampus, the neocortex, and other regions of the brain depends mainly on synaptic size and the content of AMPARs. Long-term potentiation at many central synapses depends on the delivery of AMPARs (i.e., exocytosis) that contain GluA1 to the postsynaptic site $[18,19]$ and is linked with an increase in dendritic spine size [20]. Long-term depression is associated with the removal of AMPARs (i.e., endocytosis) from the synapse and shrinkage of dendritic spines [21]. Long-term depression may occur both presynaptically through the alleviation of glutamate release or postsynaptically through the internalization of AMPARs. There are two types of LTD: NMDA-dependent and mGluR-dependent [22]. NMDA-LTD is evoked by low-frequency stimulation. Slow $\mathrm{Ca}^{2+}$ flux through NMDARs activates calcineurin ( $\left.\mathrm{CaN}\right)$ phosphatase, which dephosphorylates the GluA1 subunit of AMPARs at Ser-845, causing the endocytosis of receptors [23]. mGluR-LTD is mediated mainly by group I mGluRs, but the mechanism is much more elusive [24]. The dysfunction of mGluR-LTD (but not NMDA-LTD) is associated with learning impairment in mouse models of aging and several neurodegenerative disorders [10]. Molecular entities that are implicated in synaptic plasticity-induced $\mathrm{Ca}^{2+}$ signaling include not only glutamate receptors but also depolarization-activated channels (e.g., voltage-gated $\mathrm{Ca}^{2+}$ channels [VGCCs]) and $\mathrm{ER} \mathrm{Ca}^{2+}$ release via $\mathrm{IP}_{3} \mathrm{Rs}$ and ryanodine receptors (RyRs) [25].

Although glutamate plays an important role in physiological conditions, excessive glutamate concentrations that result in glutamate excitotoxicity can also cause the dysfunction and degeneration of neurons. Glutamate is the main excitatory neurotransmitter in the CNS, and its effects are far-reaching. Acute CNS insults, including traumatic brain injury (TBI) and cerebral ischemia, have been studied in this context. Glutamate excitotoxicity is also associated with chronic neurodegenerative disorders, including, among others, Alzheimer's disease (AD), Parkinson's disease (PD), and Huntington's disease (HD) [11]. Prolonged exposure to glutamate and the associated excessive influx of ions into 
the cell can lead to $\mathrm{Ca}^{2+}$ overload [26,27]. In the CNS, $\mathrm{Ca}^{2+}$ influx is mediated mainly by VGCCs and ionotropic glutamate receptors, such as NMDARs and AMPARs [28]. It is also complemented by stromal interaction molecule (STIM)-dependent store-operated $\mathrm{Ca}^{2+}$ entry (SOCE) [28].

The present review provides an overview of the current state of knowledge on STIM proteins and SOCE contribution to the regulation of neuronal $\mathrm{Ca}^{2+}$ homeostasis under physiological conditions (e.g., synaptic plasticity, synaptic transmission, and trafficking) and under pathological conditions (e.g., TBI, cerebral ischemia, AD, and HD) in the context of the relationship between STIM proteins and glutamate receptors. A detailed plan of our study is presented in Figure 1.

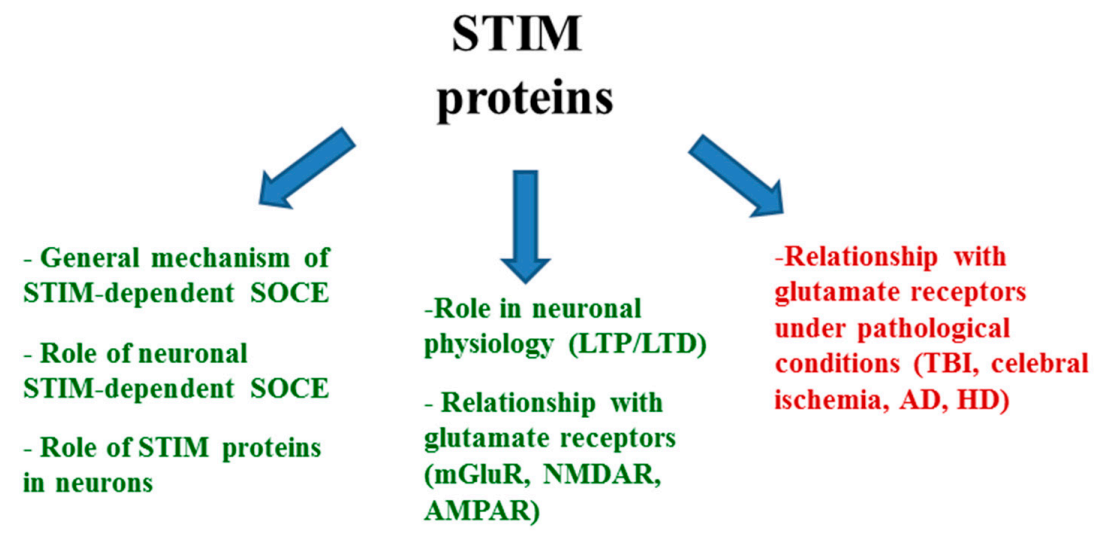

Figure 1. STIM proteins in neurons.

\section{STIM Proteins under Physiological Conditions}

\subsection{STIM Proteins and Intracellular $\mathrm{Ca}^{2+}$ Regulation}

Two STIM isoforms, STIM1 and STIM2, are $\mathrm{Ca}^{2+}$ sensors that are localized in the ER, but STIM1 was also found in the plasma membrane (PM) [29]. In resting cells, with the ER full of $\mathrm{Ca}^{2+}$, STIMs have diffuse localization (Figure 2A). The release of $\mathrm{Ca}^{2+}$ from the ER into the cytoplasm results in STIM protein oligomerization (Figure 2B). Then the oligomers migrate to ER-PM junctions and interact with Orai1-3 $\mathrm{Ca}^{2+}$ channels (Figure 2C). Interactions between STIMs and Orais lead to the formation of large complexes that are visible under microscope as distinct puncta [30,31]. As a result of this interaction, $\mathrm{Ca}^{2+}$ flows from the extracellular space into the cytoplasm in a mechanism called SOCE (Figure 2C) [32,33]. The sarco-endoplasmic reticulum $\mathrm{Ca}^{2+}$-adenosine triphosphatase (SERCA) pump then transports $\mathrm{Ca}^{2+}$ to the ER, thus refilling ER stores [34].

SOCE is the main $\mathrm{Ca}^{2+}$ entry pathway into non-excitable cells [35-37]. Accumulating evidence also indicates its significant role in neurons in different regions of the CNS, including the hippocampal pyramidal neurons [38-40], cortical pyramidal neurons [41,42], and cerebellar Purkinje neurons [5]. STIM-mediated $\mathrm{Ca}^{2+}$ influx was shown to contribute to cellular and systemic phenotypes also in Drosophila neurons [43]. Although both STIM isoforms are found in the CNS, STIM1 is the predominant isoform in the cerebellum [5,41,44], and STIM2 is more abundant in the hippocampus $[44,45]$ and cortex [29,44]. Previously, we reported formation of complexes of exogenous [41] (see also Figure 2, upper panels) and endogenous [46] STIM isoforms with Orai1 and different roles of both STIMs in neuronal SOCE [42]. The function of STIM1 protein in SOCE is undeniable, but less is known about STIM2. STIM2 has lower affinity for $\mathrm{Ca}^{2+}$ and migrates to the ER-PM junction in response to small changes in ER $\mathrm{Ca}^{2+}$ levels [42,46-48]. However, the coupling of STIM2 and Orai1 is weak and results in poor channel activation [29,49]. For these reasons, STIM2 is thought to stabilize basal $\mathrm{Ca}^{2+}$ levels $[42,46,47]$. Recent studies have identified a role for STIM2 in the activation of STIM1 and STIM1/Orai1 coupling when ER $\mathrm{Ca}^{2+}$ levels are not sufficiently low to activate the STIM1 response [49]. After the minimal depletion of ER stores, STIM2 recruits and causes the transition of STIM1 to its active conformation, which enables STIM1 coupling and the activation of Orai1. This suggests that STIM2 may 
increase the sensitivity of SOCE and maximize Orai1 function when the stimulus intensity is low [49]. Another study found a weak association between STIM1 and Orai1 in rat hippocampal neurons that lacked STIM2, suggesting that STIM2 may also facilitate STIM1 and Orai1 co-localization [50].

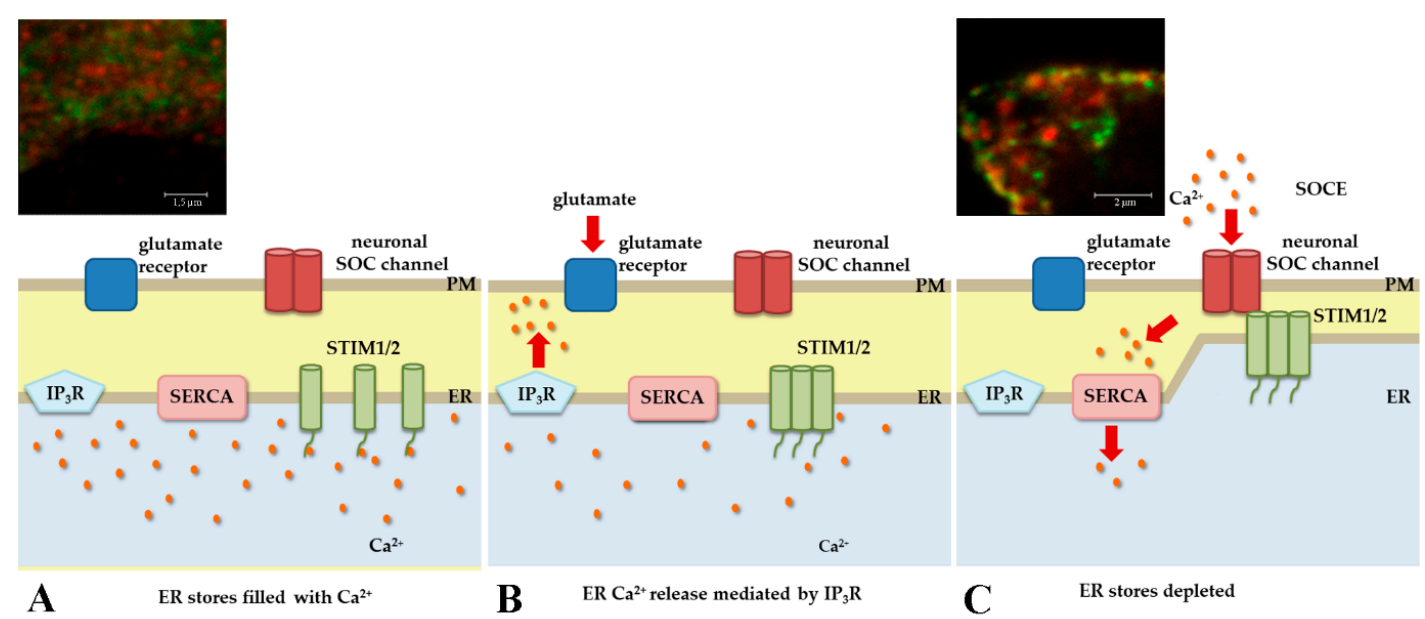

Figure 2. Model of coupling between STIM1/2 proteins and Orai channels during SOCE. (A) In the absence of external stimuli, STIM1/2 proteins are equally distributed throughout ER membrane and $\mathrm{ER} \mathrm{Ca}{ }^{2+}$ concentration is high. (B) After glutamate activation, $\mathrm{IP}_{3} \mathrm{R}$ depletes $\mathrm{ER} \mathrm{Ca}^{2+}$ stores. $\mathrm{Ca}^{2+}$ dissociates from STIM1/2 N-terminal domain which results in STIM1/2 oligomerization and translocation to the PM. (C) STIM1/2 binds to Orai1, thereby activating SOCE. Then, SERCA pump transports $\mathrm{Ca}^{2+}$ from cytoplasm to ER to refill the stores with $\mathrm{Ca}^{2+}$. $(\mathrm{A}, \mathbf{C})$ The upper panels show confocal images of neurons co-expressing Orai1 (red) and YFP-STIM1 (green) before (A) and after store depletion by thapsigargin $(\mathbf{C})$ where the proteins are redistributed equally and colocalized forming the complexes (yellow), respectively (modified from images in [41] with permission from Elsevier).

New evidence suggests that neuronal STIM-mediated SOCE preserves ER $\mathrm{Ca}^{2+}$ levels, participates in the regulation of spine morphogenesis, influences neuronal $\mathrm{Ca}^{2+}$ dynamics during synaptic excitation, and regulates gene expression [51]. Although the influence of STIM1 on spine architecture is unclear [51], STIM2 was shown to maintain hippocampal postsynaptic mushroom spines [29,52]. Low ER Ca ${ }^{2+}$ content activates STIM2-mediated SOCE, which supports a constant level of the $\mathrm{Ca}^{2+}$-CAMKII complex and stabilizes mushroom spines that participate in memory storage [29]. In turn, STIM1 was shown to play a role in neurogenesis [53]. SOCE is the major $\mathrm{Ca}^{2+}$ entry pathway, which regulates gene expression and proliferation of neural progenitor cells (NPCs). Both the suppression and deletion of STIM1 or Orai1 significantly alleviate the proliferation of embryonic and adult NPCs [53]. STIM1 knockdown also decreases the proliferation and early differentiation of human NPCs [54]. In addition to Orai activation, STIM proteins may induce $\mathrm{Ca}^{2+}$ influx via TRPCs [5,55]. TRPC1 and Orai1 activation is mediated by different STIM1 domains. TRPC1 function depends on Orai1-mediated $\mathrm{Ca}^{2+}$ influx, which triggers the recruitment of TRPC1 into the PM where it is activated by STIM1. TRPC1 is thought to modify the initial $\mathrm{Ca}^{2+}$ signal that is caused by Orai1 activation [55]. Moreover, two research groups independently discovered a direct interaction between STIM1 protein and L-type VGCCs [56,57]. According to these studies, STIM1 suppresses the depolarization-mediated opening of L-type VGCCs. Interestingly, it is mediated by the same domain that activates neuronal store-operated channels (SOCs) [58]. The influence of STIM1 on VGCCs is also associated with an increase in channel internalization from the PM. STIM1 was also shown to control the structural plasticity of L-type VGCC-dependent dendritic spines. The NMDAR activation of L-type VGCCs was postulated to trigger $\mathrm{Ca}^{2+}$ release from the ER, which in turn causes STIM1 aggregation and inhibits L-type VGCCs, thus enhancing ER spine content and stabilizing mushroom spines [59]. In turn, STIM1 in complex with TRPC1 was shown to associate and inhibit L-type VGCCs as Cav1.3, which is essential for the protection 
of dopaminergic neurons in the substantia nigra region [60]. Loss of dopaminergic neurons leads to PD, however, the mechanism of its development is not fully understood. Neuronal death and degeneration seen in PD as well as in AD and HD may be caused by, among other things, the inhibition of the ubiquitin-proteasome system (UPS) [61]. Importantly, UPS regulates STIMs distribution and SOCE function [61,62]. This suggests that $\mathrm{Ca}^{2+}$ shortage is an early event in neurodegeneration associated with UPS inhibition observed in these diseases. The above results deliver some better insight into the contribution of STIM proteins in neurodegeneration mechanisms.

\subsection{STIM Proteins and Their Relationship with Glutamate Receptors}

Increasingly more research is focusing on the influence of STIM proteins on glutamate receptors. $\mathrm{Ng}$ et al. showed that the activation of group I mGluRs stimulates STIM1 oligomerization and its transport to the PM [63]. This is consistent with a study by Hartmann's group, who discovered that STIM1 protein is responsible for mGluR1-dependent synaptic transmission in cerebellar Purkinje neurons (PNs) and controls cerebellar motor behavior [5]. In mice with the PN-specific deletion of STIM1, mGluR1-dependent signaling was abolished. Interestingly, both $\mathrm{IP}_{3}$-dependent $\mathrm{Ca}^{2+}$ release from the ER and TRPC3-mediated slow excitatory postsynaptic currents were impaired. The disruption of these two pathways abolished cerebellar motor behavior [5]. Our study revealed that AMPARs in primary rat cortical neurons can interact with STIM proteins in a SOCE-dependent manner, thus demonstrating that STIM proteins can induce $\mathrm{Ca}^{2+}$ influx not only via Orai and TRPCs, but also through AMPARs [64]. AMPAR antagonists inhibit SOCE, and SOCE inhibitors decrease AMPA-induced $\mathrm{Ca}^{2+}$ influx. Additionally, the induction of SOCE by thapsigargin (TG) results in both direct and indirect AMPAR activation. We also found that both STIM1 and STIM2 proteins cooperate with GluA1 and GluA2 subunits of AMPARs. Although these interactions occur mainly in pyramidal neurons, they may also occur in non-pyramidal cells [64]. Garcia-Alvarez et al. showed that STIM2 protein can interact with AMPARs in a SOCE-independent manner [65]. STIM2 induces the cAMP/PKA-dependent surface delivery of GluA1 through exocytosis and endocytosis. The authors suggested that STIM2 couples PKA to AMPARs and promotes the phosphorylation of GluA1 at Ser-845. The phosphorylation of Ser-845 is widely known to regulate the activity-dependent trafficking and surface delivery of AMPARs. Surprisingly, STIM2 and the phosphorylation of GluA1 at Ser-831 are negatively correlated. In STIM2-silenced neurons, the phosphorylation of GluA1 is increased at Ser-831. Altogether, these findings indicate that STIM2 regulates the phosphorylation of GluA1 at both Ser-845 and Ser-831 [65].

Importantly, both serine residues, Ser-845 and Ser-831, play a pivotal role in LTP and LTD (i.e., forms of synaptic plasticity that are responsible for learning and memory) [65]. Yap et al. confirmed the role of STIM2 protein in LTP and LTD at hippocampal synapses [66]. The authors also found that the phosphorylation of GluA1 at Ser-845 is only one of the mechanisms by which STIM2 influences AMPAR delivery during LTP. In mice that lacked the GluA1 Ser-845 phosphorylation site, LTP was unchanged [67]. Other mechanisms also control the synaptic delivery of GluA1 during LTP [68]. Yap's group speculated that STIM2 may likely participate in these mechanisms [66]. Mice with double Stim1/Stim2 conditional knockout (cKO) exhibited an enhancement of LTP, which was associated with increases in the phosphorylation of GluA1, the transcriptional regulator CREB, and L-type VGCCs at PKA sites [69]. The ablation of Stim genes in the forebrain results in spatial memory impairments, similar to such impairments that are caused by NMDAR blockade [45]. This indicates an inverse correlation between spatial learning/memory and LTP. An increase in cAMP/PKA signaling impairs learning and memory functions [69]. Baba et al. suggested that SOCE may impact LTP by influencing NMDARs [39]. The activation of NMDARs in pyramidal neurons results in SOCE activation. NMDAR stimulation leads to the recruitment of $\mathrm{IP}_{3}$, which in turn interacts with $\mathrm{IP}_{3} \mathrm{R}$, causing $\mathrm{Ca}^{2+}$ release from ER stores and the activation of SOCE. SOCE inhibitors decrease NMDA-dependent $\mathrm{Ca}^{2+}$ influx and synaptic plasticity in the hippocampus [39]. Nevertheless, Emptage et al. showed that the depletion of ER stores triggered SOCE in presynaptic neurons, thus influencing the frequency of spontaneous neurotransmitter release [38]. Therefore, the possibility that SOCE inhibitors prevent LTP by affecting 
presynaptic SOCE cannot be excluded. The PN-specific deletion of STIM1 reduced neuronal excitability and weakened intrinsic plasticity, but it did not affect LTP. These results suggest that STIM1 in PNs is essential for intrinsic plasticity but not for synaptic plasticity [70]. Other studies also reported a role for STIM1 and SOCs in the plasticity and maintenance of dendritic spines [71,72].

In contrast to LTP, LTD is mediated by the endocytosis of AMPARs from synaptic sites. A decrease in NMDA-mediated LTD was recently reported in Stim 2 cKO mice [66]. Although the precise mechanism by which STIM2 influences LTD is unknown, it is likely associated with phosphorylation of the GluA1 subunit of AMPARs at Ser-845 [66]. Mice with a serine-to-alanine mutation at this site exhibited LTD impairment that resembled Stim 2 cKO mice [66]. In primary cortical neurons, SOCE is required for mGluR-dependent LTD [24]. The inhibition of SOCE causes the impairment of (S)-3,5-dihydroxyphenylglycine (DHPG)-induced LTD. The SOCE inhibitor YM-58483 disrupts DHPG-induced LTD and the maintenance of DHPG-mediated cytosolic $\mathrm{Ca}^{2+}$ signals. These results suggest that SOCE is essential for the activation of downstream mGluR effectors. On the other hand, Majewski et al. found that mGluR signaling is impaired in STIM1-overexpressing mouse hippocampal neurons, with no changes in LTP or basal synaptic transmission [73]. In these neurons, both electrically and chemically induced LTD was decreased [73]. L- and T-type VGCCs were shown to be important for mGluR-mediated LTD [74,75], and STIM1 protein was shown to inhibit L-type VGCCs [56,57]. Therefore, one speculation is that mGluR-mediated LTD impairment in STIM1-overexpressing mice is linked inter alia with the STIM1-induced inhibition of L-type VGCCs [73].

\section{Relationship between STIM Proteins, Glutamate, and Glutamate Receptors under Pathological Conditions}

\subsection{Traumatic Brain Injury}

Traumatic brain injury (TBI) generally results from a jolt or blow to the head, but it may also be caused by a penetrating head injury [76]. It causes the disruption of normal brain function. Two kinds of damage can be caused by brain injury: primary damage and secondary damage. Primary damage occurs at the moment of injury. Secondary damage is initiated after the trauma and may last for several months or longer [77]. The most important pathological mechanism of secondary brain injury is an elevation of glutamate release, which can lead to the excessive stimulation of glutamate receptors (Figure 3). This is followed by an increase in cytoplasmic $\mathrm{Ca}^{2+}$ levels (i.e., $\mathrm{Ca}^{2+}$ overload), which in turn triggers downstream lethal cascades and is considered to be the main cause of neuronal apoptotic death after TBI. $\mathrm{Ca}^{2+}$ overload in TBI can be driven by both $\mathrm{Ca}^{2+}$ release from the ER and $\mathrm{Ca}^{2+}$ influx from the extracellular space through glutamate receptors, VGCCs or SOCE [78]. Interestingly, in an in vitro model of TBI, SOCE was enhanced $3 \mathrm{~h}$ after injury [79]. Numerous studies have demonstrated a significant contribution of mGluRs to glutamate-mediated pathological $\mathrm{Ca}^{2+}$ accumulation $[3,80]$. The glutamate-induced activation of mGluR1 is associated with both $\mathrm{Ca}^{2+}$ release from ER stores $[11,81]$ and its influx through SOCs [82]. The former mechanism is mediated by $\mathrm{IP}_{3} \mathrm{R}$ - and/or RyR-dependent rapid $\mathrm{Ca}^{2+}$ release from intracellular stores. The latter mechanism operates as slow $\mathrm{Ca}^{2+}$ influx from the extracellular space. Since STIM1 is a $\mathrm{Ca}^{2+}$ sensor located in the ER that is known to play a role in neuronal injury, the influence of this protein on mGluRs has become an interesting focus of research. Hou et al. reported that mGluR-dependent $\mathrm{IP}_{3} \mathrm{R}$ - and/or RyR-mediated $\mathrm{Ca}^{2+}$ release from the ER after traumatic neuronal injury (TNI) in STIM1-deficient mice was significantly alleviated [82]. In the absence of STIM1, the ER is largely devoid of $\mathrm{Ca}^{2+}$; therefore, mGluR1-mediated signaling cannot induce $\mathrm{Ca}^{2+}$ release from intracellular stores. This mechanism indicates that STIM1 might link mGluR1 with its downstream effectors, which is consistent with previous findings [5]. The downregulation of reticulon protein 1-C (a member of membrane-bound proteins in the ER) was recently shown to protect cortical neurons against TNI by preserving intracellular $\mathrm{Ca}^{2+}$ homeostasis. This neuronal protection was associated with the inhibition of ER $\mathrm{Ca}^{2+}$ release via a mGluR1-dependent pathway and a reduction of STIM1 expression (with no effect on the expression of STIM2 or Orai1) and SOCE-mediated $\mathrm{Ca}^{2+}$ influx [83]. Therefore, STIM1 downregulation may inhibit apoptotic cell 
death after TBI and improve neuronal viability $[82,83]$. In contrast to the above findings, Rao et al. discovered that STIM2 expression was upregulated and STIM1 expression was unchanged after TBI in both in vitro and in vivo experiments [84]. The downregulation of STIM2 (but not STIM1) preserves neurological function and decreases apoptosis, thus improving neuronal survival. Neuroprotection that was conferred by decreasing ER $\mathrm{Ca}^{2+}$ release and reducing SOCE after STIM2 knockdown was associated with a reduction of $\mathrm{Ca}^{2+}$ overload. Since STIM2 is considered to support the development of secondary brain injury, the authors speculated that it may be a potential therapeutic target for the treatment of TBI [84].

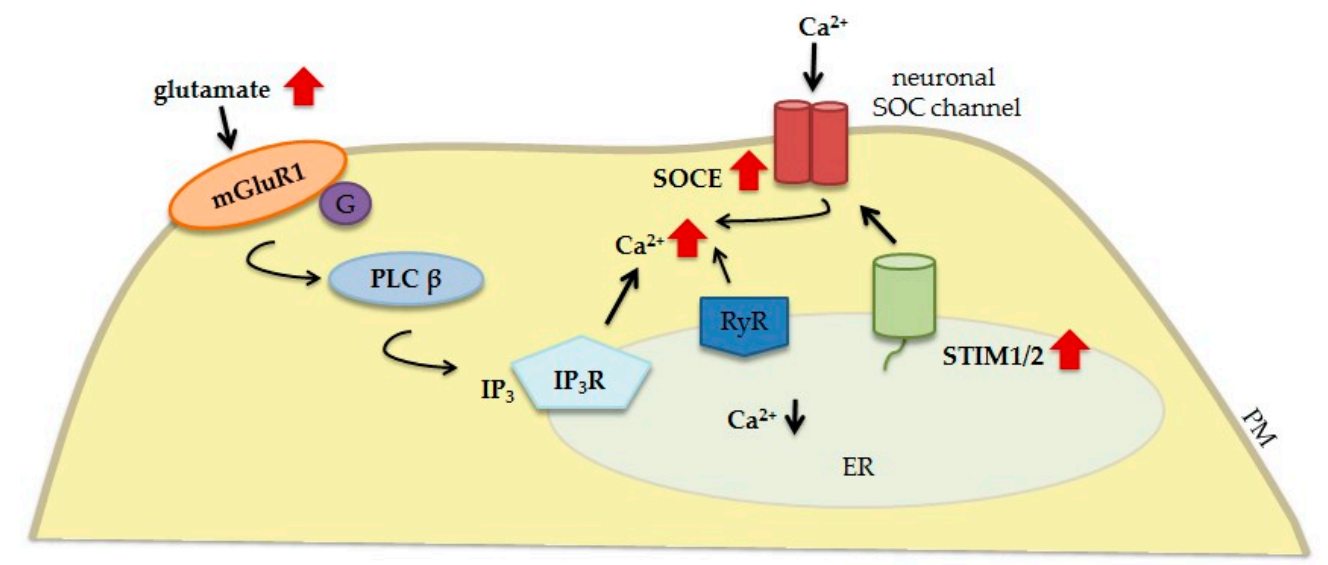

Figure 3. Contribution of neuronal STIM proteins and glutamate receptors to $\mathrm{Ca}^{2+}$ signaling dysregulation in TBI. The elevation of glutamate release leads to the excessive stimulation of glutamate receptors (e.g., mGluR1). mGluR1 couples to G $\alpha$-protein, which activates PLC $\beta$ and induces the formation of $\mathrm{IP}_{3}$ that interacts with $\mathrm{IP}_{3} \mathrm{Rs}$, causing the release of $\mathrm{Ca}^{2+}$ from ER stores. mGluR1 also contributes to RyR-mediated $\mathrm{Ca}^{2+}$ leakage, resulting in lower $\mathrm{ER} \mathrm{Ca}^{2+}$ levels, which in turn activate STIM proteins and promote SOCE that contributes to $\mathrm{Ca}^{2+}$ overload. Solid black arrows represent the interaction mechanisms; red solid arrows symbolize increased expression/concentration.

\subsection{Cerebral Ischemia}

Cerebral ischemia is a pathological condition that is caused by the insufficient supply of oxygen and nutrients to the brain, which may result from embolism, thrombosis, or systemic hypoperfusion [85]. Under low oxygen tension and low glucose levels, neurons lose their energy stores and become depolarized, while also releasing excessive glutamate into the extracellular space. The resulting overstimulation of glutamate receptors, particularly NMDARs, causes the excessive influx of $\mathrm{Ca}^{2+}$ ions (i.e., $\mathrm{Ca}^{2+}$ overload) and initiates ischemic brain damage and cell death [86] (Figure 4). Berna-Erro et al. found that STIM2 (but not STIM1) is essential for intracellular $\mathrm{Ca}^{2+}$ accumulation during cerebral ischemia [45]. Under hypoxic/hypoglycemic conditions, adenosine triphosphate-dependent $\mathrm{Ca}^{2+}$ transport to the ER is inhibited, which triggers persistent STIM2 activation and SOCE-mediated $\mathrm{Ca}^{2+}$ accumulation [29]. Importantly, SOCE may also trigger $\mathrm{Ca}^{2+}$ influx by increasing the release of glutamate and activating ionotropic receptors [45]. The combination of SOCE and glutamatergic $\mathrm{Ca}^{2+}$ inflow may rapidly increase $\mathrm{Ca}^{2+}$ concentrations to a dangerous level. Additionally, the lack of STIM2 decreases $\mathrm{Ca}^{2+}$ overload during an ischemic challenge. In acute hippocampal slices and hippocampal neurons in culture that were isolated from Stim $2 \mathrm{KO}$ mice, SOCE is diminished and ER content is lower, so these animals are better able to survive hypoxic conditions. Stim $2 \mathrm{KO}$ mice are better protected against cerebral ischemia compared with wildtype mice [45]. Another study suggested that STIM1 also contributes to pathological changes that occur in ischemia. The higher expression of STIM1 and Orai1 in the rat hippocampus after global cerebral ischemia was shown to enhance intracellular $\mathrm{Ca}^{2+}$ concentrations [87]. The resulting ischemia-induced neuronal death was attenuated by Stim1 siRNA. The suppression of STIM1 in the early stage of ischemia attenuates neuronal death by 
inhibiting SOCE-induced neuronal apoptosis [87]. Moreover, mouse STIM1-deficient platelets were protected from neuronal damage after temporary cerebral ischemia [88]. These findings indicate that STIM proteins may be a new target for the treatment of ischemic stroke.

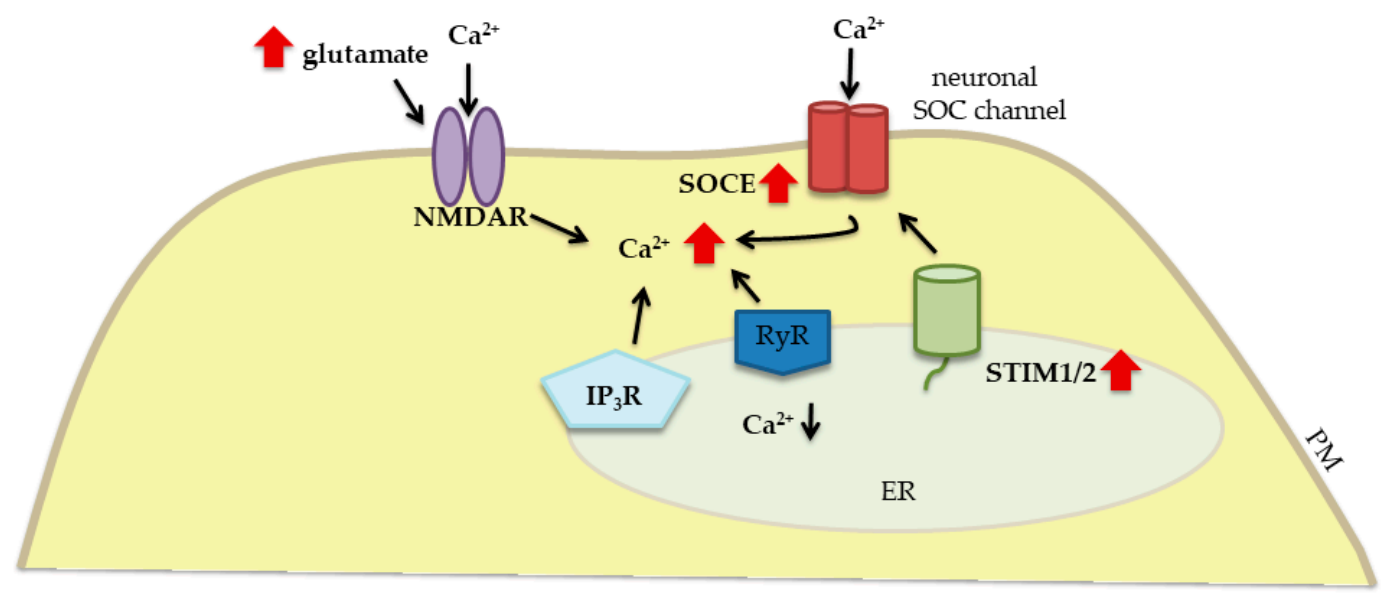

Figure 4. Contribution of neuronal STIM proteins and glutamate receptors to $\mathrm{Ca}^{2+}$ signaling dysregulation in cerebral ischemia. The elevation of glutamate release leads to the excessive stimulation of glutamate receptors (e.g., NMDARs). The overactivation of NMDARs results in excessive $\mathrm{Ca}^{2+}$ influx from both the extracellular space and ER stores, resulting in lower ER $\mathrm{Ca}^{2+}$ levels, which in turn promote STIM-mediated SOCE and contribute to $\mathrm{Ca}^{2+}$ overload. Solid black arrows represent the interaction mechanisms; red solid arrows symbolize increased expression/concentration.

\subsection{Alzheimer's Disease}

Alzheimer's disease is the most common neurodegenerative disorder. Each year, it affects over 5 million people worldwide [28]. Alzheimer's disease patients suffer from memory loss and cognitive impairment. In most cases, the first symptoms occur after 65 years of age (sporadic/late-onset AD). However, in some cases, the onset is earlier and is generally caused by mutations of genes that encode amyloid precursor protein (APP), presenilin-1 (PS1), and presenilin-2 (PS2; early-onset AD or familial AD [FAD]) [89]. Presenilins are enzymes that process integral membrane proteins, such as APP. Amyloidogenic APP processing results in the formation of neurotoxic forms of $\beta$-amyloid (A $\beta$ ). In AD patients, these peptides accumulate in extracellular plaques, causing neuronal death in the cerebral cortex and hippocampus. Nevertheless, recent research suggests that soluble $A \beta$ oligomers, rather than amyloid plaques, cause neuronal dysfunction [28,90-92]. Busche et al. suggested that $A \beta$ oligomers disrupt the balance between synaptic excitation and inhibition, resulting in the hyperactivation of cortical and hippocampal neurons and leading to $\mathrm{Ca}^{2+}$ overload [90] (Figure 5). $\beta$-amyloid enhances intracellular $\mathrm{Ca}^{2+}$ levels via multiple mechanisms. It affects synaptic NMDAR and mGluR5 activity [93-95], increases RyR-mediated $\mathrm{Ca}^{2+}$ leakage from the ER [96], and influences several $\mathrm{Ca}^{2+}$ entry pathways [97]. RyR-dependent $\mathrm{Ca}^{2+}$ release may be driven by $\mathrm{Ca}^{2+}$ influx via AMPARs, NMDARs, and VGCCs, especially in dendritic spines that lack $\mathrm{IP}_{3} \mathrm{Rs}$ [98]. Glutamate also activates mGluR1/5 and $\mathrm{IP}_{3} / \mathrm{IP}_{3} \mathrm{R} 1$-mediated $\mathrm{Ca}^{2+}$ release from the ER [99]. According to Zhang et al., hippocampal ER $\mathrm{Ca}^{2+}$ stores are refilled through the activation of mGluR5, which in turn leads to higher ER $\mathrm{Ca}^{2+}$ concentrations [94]. The refilling of mGluR1/5-mediated $\mathrm{Ca}^{2+}$ stores mainly depends on STIM1 [5]. In the cortex in sporadic AD patients, in the hippocampus in aged normal mice, and in a transgenic mouse model of FAD, ER Ca ${ }^{2+}$ overload results in the compensatory downregulation of STIM2 expression, impairments in synaptic SOCE, and lower CaMKII activity [52,94]. Insufficient CaMKII activation and an increase in CaN activity disturb the balance between LTP and LTD, facilitating LTD. The result is the destabilization of mushroom spines that are responsible for memory storage [99]. The pharmacological overexpression of STIM2 or inhibition of mGluR5 rescues synaptic SOCE and prevents the loss of mushroom spines in APP knock-in hippocampal neurons [94]. STIM2 protein also rescues CaMKII 
activity and protects dendritic spines against amyloid toxicity [94,100]. Presenilin-mediated synaptic deficits in AD were also postulated to be mediated by the dysregulation of neuronal SOCE [52,101]. In mouse embryonic fibroblasts with the lack of presenilins, STIM1 levels increased, whereas STIM2 expression decreased [102]. In these cells, SOCE was enhanced after $\mathrm{Ca}^{2+}$ store depletion. In turn, PS1 overexpression in human embryonic kidney 293 cells attenuated SOCE. Although no changes in STIM protein expression were observed in these cells, STIM2 expression decreased in human B lymphocytes with a PS1 mutation, which was paralleled by the alleviation of SOCE [102]. This is consistent with studies that were conducted with mouse hippocampal neurons. Mature spines from mutant PS1 mice exhibited a decrease in STIM2 expression and impairments in SOCE [52]. Impairments in SOCE and a reduction of synaptic STIM2 protein expression resulted in dendritic spine destabilization in mutant PS mice [52]. In mouse primary cortical neurons and human neuroblastoma SH-SY5Y cells, FAD PS1 increased $\gamma$-secretase cleavage of the STIM1 transmembrane domain, thus attenuating SOCE, which in turn destabilized dendritic spines. Both the overexpression of STIM1 protein and the inhibition of $\gamma$-secretase rescued dendritic spine loss [101]. Familial Alzheimer's disease PS2, but not FAD PS1, in both SH-SY5Y cells and FAD patient-derived fibroblasts altered $\mathrm{ER} \mathrm{Ca}^{2+}$ content by partially blocking SERCA activity [103]. Additionally, both FAD PS1 and PS2 mutants reduced SOCE, diminishing STIM1 expression [103]. In turn, Zhang et al. found that TRPC6 and Orai2 are neuronal SOCs that participate in SOCE in mature dendritic spines [104]. The knockdown of TRPC6/Orai2 resulted in SOCE inhibition and the loss of dendritic spines in wildtype neurons [104]. The TRPC6 activator hyperforin and novel neuronal SOC modulator NSN attenuated the loss of dendritic spines in APP and PS knock-in mice [104]. The stabilization of dendritic mushroom spines is considered to prevent memory loss in AD patients. Therefore, the modification of STIMs and SOCE may confer potential therapeutic benefit for the treatment of memory loss in AD patients.

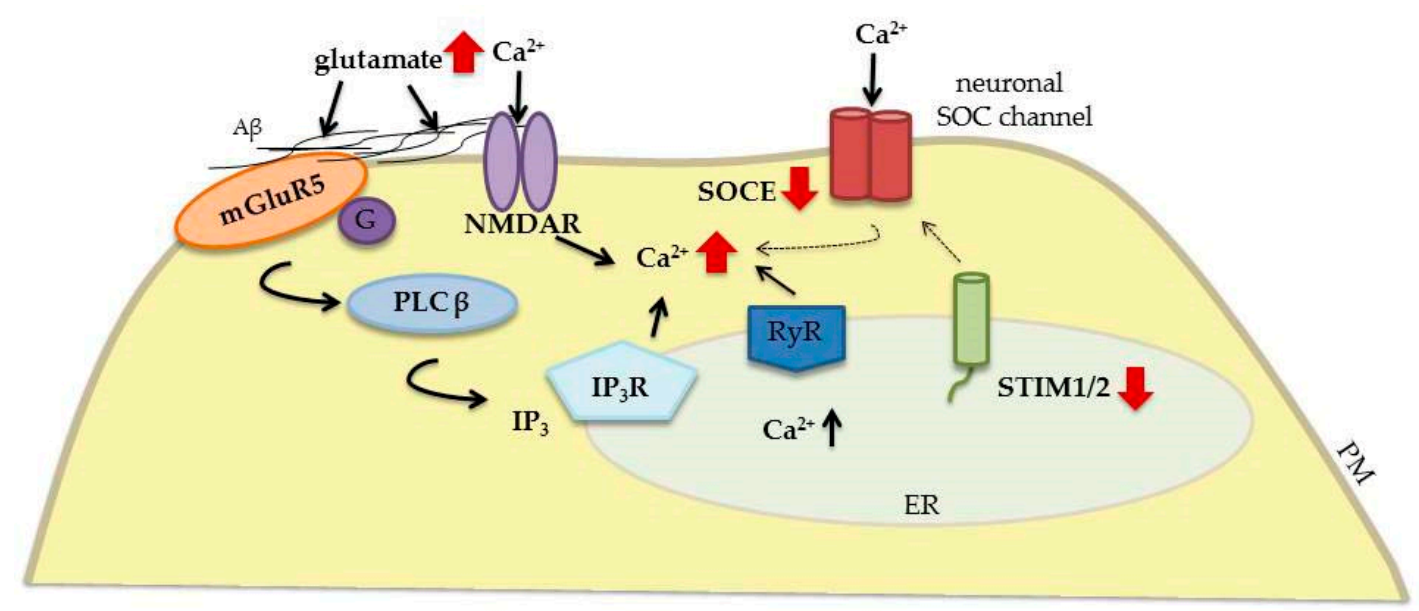

Figure 5. Contribution of neuronal STIM proteins and glutamate receptors to $\mathrm{Ca}^{2+}$ signaling dysregulation in AD. Elevations of both $\mathrm{A} \beta$ expression and glutamate release lead to the excessive stimulation of glutamate receptors (e.g., NMDARs and mGluR5). The overactivation of NMDARs results in excessive $\mathrm{Ca}^{2+}$ influx. In turn, mGluR5 couples to $\mathrm{G} \alpha$-protein, which activates PLC $\beta$ and induces the formation of $\mathrm{IP}_{3}$, which interacts with $\mathrm{IP}_{3}$ Rs and increases $\mathrm{Ca}^{2+}$ concentrations in the ER. Both pathways contribute to $\mathrm{Ca}^{2+}$ overload. The result of $\mathrm{ER} \mathrm{Ca}^{2+}$ deprivation is STIM downregulation, which alleviates SOCE. Solid black arrows represent the interaction mechanisms, dotted black arrows mean attenuated mechanisms, and red solid arrows symbolize increased (up) or decreased (down) expression/concentration.

\subsection{Huntington's Disease}

Huntington's disease is an autosomal dominant neurodegenerative disorder that results from the expansion of a CAG repeat in the huntingtin gene (HTT), which is translated to polyglutamine (polyQ) 
in the huntingtin protein (HTT) $[28,105]$. The number of CAG repeats normally does not exceed 36; in HD patients, however, it is higher than 36. Mutant HTT (mHTT) causes the dysfunction of striatal neurons, synaptic loss, and eventually neuronal degeneration [106]. Neurodegeneration initially occurs mainly in the striatum and cortex. However, in later stages of the disease, it extends to various brain regions $[107,108]$. Huntington's disease is characterized by numerous changes at the molecular level, including disturbances in $\mathrm{Ca}^{2+}$ homeostasis $[105,109]$. Studies of transgenic mice with mHTT revealed that NMDAR activation, accompanied by excitotoxicity and an increase in intracellular $\mathrm{Ca}^{2+}$ levels, was a significant pathogenic event in $\mathrm{HD}[105,110]$ (Figure 6). Elevations of $\mathrm{Ca}^{2+}$ concentrations also resulted from $\mathrm{Ca}^{2+}$ efflux via RyRs and $\mathrm{IP}_{3} \mathrm{R} 1$ [110] and the activation of group I mGluRs [105,111]. In striatal medium spiny neurons (MSNs) that were isolated from YAC128 HD transgenic mice, mHTT bound to $\mathrm{IP}_{3} \mathrm{R} 1$ after mGluR1 activation, increasing its sensitivity to $\mathrm{IP}_{3}$, which persistently reduced ER $\mathrm{Ca}^{2+}$ levels [106]. In MSNs, the decrease in ER Ca ${ }^{2+}$ concentration overactivated synaptic SOCE and enhanced STIM2 expression, which resulted in the disruption of dendritic spines [106,112]. In YAC128 MSNs, the knockdown of $\mathrm{IP}_{3}$ Rs or STIM2 was shown to normalize SOCE and prevent dendritic spine loss, thus resulting in neuroprotective effects [106]. In addition to STIM2, the knockdown of STIM1, TRPC1/TRPC6, and Orai1/Orai2 rescued spine loss in YAC128 MSNs but did not affect the spine density of wildtype MSNs [112]. Recent studies showed that the expression of huntingtin-associated protein 1A (HAP1) was elevated in the striatum in a mouse model of HD [113]. HAP1, similar to mHTT, activated SOCE by influencing $\mathrm{IP}_{3} \mathrm{R} 1[113,114]$. In human neuroblastoma cells, the HD pathological phenotype was mediated by expression of the N-terminal fragment of mHTT, which increased SOCE in a STIM1-dependent manner [115]. Similar results were observed in primary mouse cultures of MSNs and in mouse neuroblastoma cells, where the N-terminal HTT fragment enhanced SOCE through STIM1 and Orai1 or TRPC1 [116]. Moreover, tetrahydrocarbazoles were shown to attenuate the enhancement of SOCE in MSN cultures from transgenic YAC128 mice. The dysregulation of $\mathrm{Ca}^{2+}$ homeostasis is considered a pathological hallmark of $\mathrm{HD}$, and these compounds may be leading molecular structures for the treatment of HD [110]. Additionally, the SOCE inhibitor EVP4593 rescued spine loss in both in vitro and in vivo HD models, normalizing neuronal SOCE and exerting neuroprotective activity against glutamate excitotoxicity $[106,116,117]$. The pharmacological modulation of SOCE and its components may have neuroprotective effects in HD patients.

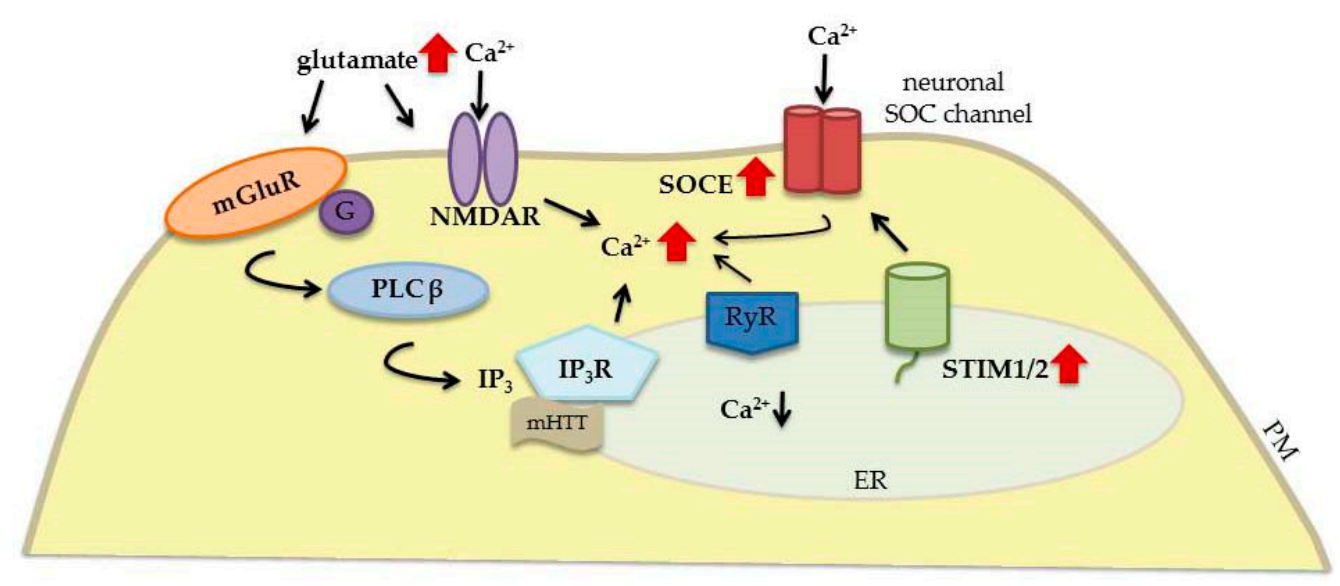

Figure 6. Contribution of neuronal STIM proteins and glutamate receptors to $\mathrm{Ca}^{2+}$ signaling dysregulation in HD. The elevation of glutamate release leads to the excessive stimulation of glutamate receptors (e.g., NMDARs and mGluRs). The overactivation of NMDARs results in excessive $\mathrm{Ca}^{2+}$ influx. In turn, mGluRs couple to G $\alpha$-protein, which activates PLC $\beta$ and induces the formation of $\mathrm{IP}_{3}$, which interacts with $\mathrm{IP}_{3} \mathrm{Rs}$ and causes the release of $\mathrm{Ca}^{2+}$ from ER stores. mHTT increases the sensitivity of $\mathrm{IP}_{3} \mathrm{R} 1$ to $\mathrm{IP}_{3}$, which additionally enhances $\mathrm{ER} \mathrm{Ca}^{2+}$ release, resulting in a decrease in $\mathrm{ER} \mathrm{Ca}^{2+}$ levels, which in turn activates STIM, promotes SOCE, and contributes to $\mathrm{Ca}^{2+}$ overload. Solid black arrows represent the interaction mechanisms; red solid arrows symbolize increased expression/concentration. 


\section{Concluding Remarks}

The experimental evidence that was reviewed in this paper clearly demonstrates a relationship between neuronal SOCE that is mediated by STIM proteins and glutamate receptors under both healthy and pathological conditions. Under physiological conditions, STIM1 mediates mGluR1-dependent synaptic transmission in cerebellar PNs, thus influencing cerebellar motor behavior [5]. In primary rat cortical neurons, SOCE is mediated by AMPAR channels that interact with STIM1 and STIM2 proteins [64]. The relationship between STIM proteins and glutamate receptors was also observed in different forms of synaptic plasticity, such as LTP and LTD (i.e., the mechanisms that are responsible for learning and memory) $[65,66,69,72,73]$. In primary rat hippocampal neurons, STIM2 induces the phosphorylation and surface delivery of the GluA1 subunit of AMPARs, which in turn contributes to LTP [65]. SOCE may also influence LTP by influencing NMDA receptors [39,59]. SOCE inhibitors decrease NMDA-dependent $\mathrm{Ca}^{2+}$ influx and synaptic plasticity in the hippocampus [39]. STIM proteins also contribute to both NMDA- and mGluR-mediated LTD, which is associated with the endocytosis of AMPARs from synaptic sites [24,66]. Although the precise influence of STIM proteins on LTD is unknown, it is probably associated with phosphorylation of the GluA1 subunit of AMPARs.

The relationship between neuronal SOCE and glutamate receptors is also observed in both acute neurodegenerative disorders (e.g., TBI and cerebral ischemia) and chronic neurodegenerative disorders (e.g., AD and HD). Nevertheless, changes in neuronal SOCE may be in opposite directions in different pathological conditions. SOCE appears to be neuroprotective in AD, whereas the blockade of this process may be neuroprotective in other neurological disorders, such as TBI, cerebral ischemia, and HD. In TBI, cerebral ischemia, and HD, neuronal ER $\mathrm{Ca}^{2+}$ stores are excessively depleted, and such depletion is associated with STIM overexpression and SOCE overactivation (Table 1). In TBI, it is mainly attributed to the stimulation of mGluRs. In cerebral ischemia, it is mainly attributed to the activation of NMDARs. In HD, it is attributed to both mGluRs and NMDARs [75,105,110,111]. The downregulation of STIMs expression eliminates the toxic effect of these proteins (Table 1). In contrast to $\mathrm{TBI}$, ischemia, and HD, in AD neuronal $\mathrm{ER} \mathrm{Ca}^{2+}$ stores are overfilled, which is assigned to mGluR and NMDAR activation [93-95]. STIMs and SOCE in AD are downregulated as a compensatory response to $\mathrm{ER} \mathrm{Ca}^{2+}$ overfilling (Table 1). Although there are some reviews in literature that discuss the role of SOCE in neuronal physiology and pathology $[28,34,92]$, this study focuses on the role of STIM1 and STIM2 proteins. Our paper not only summarizes and expands the function of SOCE and STIMs in neurons, but also indicates the relationship between STIM proteins and glutamate receptors in this case.

Table 1. Summary of the functional significance of neuronal STIM proteins in neurodegenerative diseases.

\begin{tabular}{|c|c|c|c|c|c|}
\hline Disease & $\begin{array}{l}\text { Pathological } \\
\text { Mechanism }\end{array}$ & $\begin{array}{c}\text { STIM } \\
\text { Expression }\end{array}$ & Role of STIM & Effect & References \\
\hline \multirow{2}{*}{ TBI } & \multirow{2}{*}{$\begin{array}{l}\text { Glutamate toxicity } \\
\text { mediated by } \\
\text { mGluR }\end{array}$} & $\begin{array}{c}\text { STIM1 is } \\
\text { overexpressed }\end{array}$ & \multirow{2}{*}{$\begin{array}{l}\text { - Increasing SOCE-mediated } \mathrm{Ca}^{2+} \\
\text { influx } \\
\text { - Contributing to } \mathrm{Ca}^{2+} \text { overload }\end{array}$} & \multirow{2}{*}{$\begin{array}{c}\text { toxic } \\
\text { (blockade of STIM } \\
\text { expression }->\text { protective) }\end{array}$} & {$[82,83]$} \\
\hline & & $\begin{array}{c}\text { STIM2 is } \\
\text { overexpressed }\end{array}$ & & & [84] \\
\hline \multirow{2}{*}{$\begin{array}{l}\text { Cerebral } \\
\text { ischemia }\end{array}$} & \multirow{2}{*}{$\begin{array}{l}\text { Glutamate toxicity } \\
\text { mediated by } \\
\text { NMDAR }\end{array}$} & $\begin{array}{c}\text { STIM1 is } \\
\text { overexpressed }\end{array}$ & \multirow{2}{*}{$\begin{array}{l}\text { - Increasing SOCE-mediated } \mathrm{Ca}^{2+} \\
\text { influx } \\
\text { - Contributing to } \mathrm{Ca}^{2+} \text { overload }\end{array}$} & \multirow{2}{*}{$\begin{array}{c}\text { toxic } \\
\text { (blockade of STIM } \\
\text { expression }->\text { protective) }\end{array}$} & [87] \\
\hline & & $\begin{array}{c}\text { STIM2 is } \\
\text { overexpressed }\end{array}$ & & & [45] \\
\hline \multirow{2}{*}{$\mathrm{AD}$} & \multirow{2}{*}{$\begin{array}{l}\text { Glutamate toxicity } \\
\text { mediated by mGluR } \\
\text { and NMDAR }\end{array}$} & $\begin{array}{c}\text { STIM1 is } \\
\text { downregulated }\end{array}$ & \multirow{2}{*}{$\begin{array}{l}\text { - Reducing SOCE-mediated } \mathrm{Ca}^{2+} \\
\text { influx } \\
\text { - Stabilizes dendritic spines }\end{array}$} & \multirow{2}{*}{ neuroprotective } & [101] \\
\hline & & $\begin{array}{c}\text { STIM2 is } \\
\text { downregulated }\end{array}$ & & & {$[52,94]$} \\
\hline \multirow{2}{*}{ HD } & \multirow{2}{*}{$\begin{array}{l}\text { Glutamate toxicity } \\
\text { mediated by mGluR } \\
\text { and NMDAR }\end{array}$} & $\begin{array}{c}\text { STIM1 is } \\
\text { overexpressed }\end{array}$ & \multirow{2}{*}{$\begin{array}{l}\text { - Increasing SOCE-mediated } \mathrm{Ca}^{2+} \\
\text { influx } \\
\text { - Contributing to } \mathrm{Ca}^{2+} \text { overload } \\
\text { - Disrupting dendritic spines }\end{array}$} & \multirow{2}{*}{$\begin{array}{c}\text { toxic } \\
\text { (blockade of STIM } \\
\text { expression }->\text { protective) }\end{array}$} & {$[112,116]$} \\
\hline & & $\begin{array}{c}\text { STIM2 is } \\
\text { overexpressed }\end{array}$ & & & {$[106,112]$} \\
\hline
\end{tabular}


In conclusion, the present study reveals that the restoration of physiological neuronal STIM-dependent SOCE and the normalization of STIM protein expression and glutamate receptor activity may confer potential beneficial effects for the treatment of both acute and chronic neurodegenerative diseases. Nevertheless, this approach has limitations (e.g., toxic effects on neuronal cells from nontarget regions). Undoubtedly, further studies are required in this field.

Funding: This work was supported by funds from the National Science Centre (research project no. 2017/26/E/NZ3/01144 to J.G-B).

Conflicts of Interest: The authors declare no conflict of interest.

\section{Abbreviations}

$\begin{array}{ll}\text { AD } & \text { Alzheimer's disease } \\ \text { AMPARs } & \alpha \text {-amino-3-hydroxy-5-methyl-4-isoxazolepropionic acid receptors } \\ \text { APP } & \text { amyloid precursor protein } \\ \text { CaMKII } & \mathrm{Ca}^{2+} / \text { calmodulin-dependent protein kinase II } \\ \text { CNS } & \text { central nervous system } \\ \text { ER } & \text { endoplasmic reticulum } \\ \text { HD } & \text { Huntington's disease } \\ \text { HTT } & \text { huntingtin protein } \\ \text { IP } & \text { inositol trisphosphate } \\ \text { LTD } & \text { long-term depression } \\ \text { LTP } & \text { long-term potentiation } \\ \text { mGluRs } & \text { metabotropic glutamate receptors } \\ \text { MSNs } & \text { medium spiny neurons } \\ \text { NMDARs } & \text { N-methyl-D-aspartate receptors } \\ \text { PD } & \text { Parkinson's disease } \\ \text { PNs } & \text { Purkinje neurons } \\ \text { PS1 } & \text { presenilin 1 } \\ \text { PS2 } & \text { presenilin 2 } \\ \text { RyRs } & \text { ryanodine receptors } \\ \text { SERCA } & \text { sarco-endoplasmic reticulum calcium-adenosine triphosphatase } \\ \text { SOCE } & \text { store-operated calcium entry } \\ \text { STIM } & \text { stromal interaction molecule } \\ \text { TBI } & \text { traumatic brain injury } \\ \text { TNI } & \text { traumatic neuronal injury } \\ \text { TRPC } & \text { transient receptor potential channel } \\ \text { VGCCs } & \text { voltage-gated calcium channels } \\ & \end{array}$

\section{References}

1. Zhou, Y.; Danbolt, N.C. Glutamate as a neurotransmitter in the healthy brain. J. Neural Transm. 2014, 121, 799-817. [CrossRef]

2. Michael, A.R. Revisiting AMPA Receptors as an Antiepileptic Drug Target. Epilepsy Curr. 2011, 11, 56-63.

3. Monaghan, D.T.; Jane, D.E. Biology of the NMDA Receptor, 1st ed.; CRC Press/Taylor \& Francis: Boca Raton, FL, USA, 2009; pp. 5-9.

4. Niswender, C.M.; Jeffrey, C.P. Metabotropic Glutamate Receptors: Physiology, Pharmacology, and Disease. Annu. Rev. Pharmacol. Toxicol. 2010, 50, 295-322. [CrossRef] [PubMed]

5. Hartmann, J.; Karl, R.M.; Alexander, R.P.; Adelsberger, H.; Brill, M.S.; Rühlmann, C.; Ansel, A.; Sakimura, K.; Baba, Y.; Kurosaki, T.; et al. STIM1 controls neuronal Ca² signaling, mGluR1-dependent synaptic transmission, and cerebellar motor behavior. Neuron 2014, 82, 635-644. [CrossRef] [PubMed]

6. Batchelor, A.M.; Madge, D.J.; Garthwaite, J. Synaptic activation of metabotropic glutamate receptors in the parallel Fibre-Purkinje cell pathway in rat cerebellar slices. Neuroscience 1994, 63, 911-915. [CrossRef] 
7. Hartmann, J.; Dragicevic, E.; Adelsberger, H.; Henning, H.A.; Sumser, M.; Abramowitz, J.; Blum, R.; Dietrich, A.; Freichel, M.; Flockerzi, V.; et al. TRPC3 Channels Are Required for Synaptic Transmission and Motor Coordination. Neuron 2008, 59, 392-398. [CrossRef]

8. Debanne, D.; Daoudal, G.; Sourdet, V.; Russier, M. Brain plasticity and ion channels. J. Physiol. Paris 2003, 97, 403-414. [CrossRef] [PubMed]

9. Youn, D.H. Differential roles of signal transduction mechanisms in long-term potentiation of excitatory synaptic transmission induced by activation of group I mGluRs in the spinal trigeminal subnucleus oralis. Brain Res. Bull 2014, 108, 37-43. [CrossRef] [PubMed]

10. Wang, H.; Ardiles, A.O.; Yang, S.; Tran, T.; Posada-Duque, R.; Valdivia, G.; Baek, M.; Chuang, Y.A.; Palacios, A.G.; Gallagher, M.; et al. Metabotropic Glutamate Receptors Induce a Form of LTP Controlled by Translation and Arc Signaling in the Hippocampus. J. Neurosci. 2016, 36, 1723-1729. [CrossRef]

11. Lau, A.; Tymianski, M. Glutamate receptors, neurotoxicity and neurodegeneration. Pflug. Arch. Eur. J. Physiol. 2010, 460, 525-542. [CrossRef] [PubMed]

12. Derkach, V.; Barria, A.; Soderling, T.R. $\mathrm{Ca}^{2+} /$ calmodulin-kinase II enhances channel conductance of alpha-amino-3-hydroxy-5-methyl-4-isoxazolepropionate type glutamate receptors. Proc. Natl. Acad. Sci. USA 1999, 96, 3269-3274. [CrossRef]

13. Oh, M.C.; Derkach, V.A.; Guire, E.S.; Soderling, T.R. Extrasynaptic membrane trafficking regulated by GluR1 serine 845 phosphorylation primes AMPA receptors for long-term potentiation. J. Biol. Chem. 2005, 281, 752-758. [CrossRef]

14. Banke, T.G.; Bowie, D.; Lee, H.K.; Huganir, R.L.; Schousboe, A.; Traynelis, S.F. Control of GluR1 AMPA Receptor Function by cAMP-Dependent Protein Kinase. J. Neurosci. 2000, 20, 89-102. [CrossRef]

15. Anggono, V.; Huganir, R.L. Regulation of AMPA Receptor Trafficking and Synaptic Plasticity. Curr. Opin. Neurobiol. 2012, 22, 461-469. [CrossRef]

16. Dingledine, R.; Borges, K.; Bowie, D.; Traynelis, S.F. The glutamate receptor ion channels. Pharmacol. Rev. 1999, 51, 7-61.

17. Lynch, M.A. Long-Term Potentiation and Memory. Physiol. Rev. 2004, 84, 87-136. [CrossRef]

18. Hayashi, Y.; Shi, S.H.; Esteban, J.A.; Piccini, A.; Poncer, J.C.; Malinow, R. Driving AMPA Receptors into Synapses by LTP and CaMKII: Requirement for GluR1 and PDZ Domain Interaction. Science 2000, 287, 2262-2267. [CrossRef]

19. Zamanillo, D.; Sprengel, R.; Hvalby, O.; Jensen, V.; Burnashev, N.; Rozov, A.; Kaise, K.M.M. Importance of AMPA Receptors for Hippocampal Synaptic Plasticity But Not for Spatial Learning. Science 1999, 284, 1805-1811. [CrossRef]

20. Matsuzaki, M.; Honkura, N.; Ellis-Davies, G.C.; Kasai, H. Structural basis of long-term potentiation in single dendritic spines. Nature 2004, 429, 761-766. [CrossRef]

21. Zhou, Q.; Homma, K.J.; Poo, M.M. Shrinkage of dendritic spines associated with long-term depression of hippocampal synapses. Neuron 2004, 44, 749-757. [CrossRef]

22. Bear, M.F.; Connors, B.W.; Paradiso, M.A. Neuroscience: Exploring the Brain; Lippincott Williams and Wilkins: Hagerstwon, MD, USA, 2007; p. 718.

23. Lüscher, C.; Malenka, R.C. NMDA Receptor-Dependent Long-Term Potentiation and Long-Term Depression (LTP/LTD). Cold Spring Harb. Perspect. Biol. 2012, 4, a005710. [CrossRef]

24. González-Sánchez, P.; Del Arco, A.; Esteban, J.A.; Satrústegui, J. Store-Operated Calcium Entry Is Required for mGluR-Dependent Long Term Depression in Cortical Neurons. Front Cell Neurosci. 2017, 11, 363. [CrossRef]

25. Reyes-Harde, M.; Empson, R.; Potter, B.V.L.; Galione, A.; Stanton, P.K. Evidence of a role for cyclic ADP-ribose in long-term synaptic depression in hippocampus. Proc. Natl. Acad. Sci. USA 1999, 96, 4061-4066. [CrossRef]

26. Dong, X.; Wang, Y.; Qin, Z. Molecular mechanisms of excitotoxicity and their relevance to pathogenesis of neurodegenerative diseases. Acta Pharmacol. Sin. 2009, 30, 379-387. [CrossRef]

27. Wojda, U.; Salinska, E.; Kuznicki, J. Calcium ions in neuronal degeneration. IUBMB Life 2008, 60, 575-590. [CrossRef]

28. Wegierski, T.; Kuznicki, J. Neuronal calcium signaling via store-operated channels in health and disease. Cell Calcium 2018, 74, 102-111. [CrossRef]

29. Kraft, R. STIM and ORAI proteins in the nervous system. Channels 2015, 9, 245-252. [CrossRef]

30. Potier, M.; Trebak, M. New development in the signaling mechanisms of the store-operated calcium entry pathway. Pflügers Archiv 2008, 457, 405-415. [CrossRef] 
31. Shim, A.H.; Tirado-Lee, L.; Prakriya, M. Structural and functional mechanisms of CRAC channel regulation. J. Mol. Biol. 2015, 427, 77-93. [CrossRef]

32. Cahalan, M.D. STIMulating store-operated Ca ${ }^{2+}$ entry. Nat. Cell. Biol. 2009, 11, 669-677. [CrossRef]

33. Liou, J.; Kim, M.L.; Heo, W.D.; Jones, J.T.; Myers, J.W.; Ferrell, J.E.; Meyer, T. STIM is a Ca ${ }^{2+}$ Sensor Essential for $\mathrm{Ca}^{2+}$-Store-Depletion-Triggered $\mathrm{Ca}^{2+}$ Influx. Curr. Biol. 2005, 15, 1235-1241. [CrossRef]

34. Majewski, L.; Kuznicki, J. SOCE in neurons: Signaling or just refilling? Biochim. Biophys. Acta Mol. Cell Res. 2015, 1853, 1940-1952. [CrossRef]

35. Parekh, A.B.; Putney, J.W. Store-Operated Calcium Channels. Physiol. Rev. 2005, 85, 757-810. [CrossRef]

36. Prakriya, M.; Lewis, R.S. Store-Operated Calcium Channels. Physiol. Rev. 2015, 95, 1383-1436. Available online: https://www.ncbi.nlm.nih.gov/pmc/articles/PMC4600950/ (accessed on 1 October 2015). [CrossRef]

37. Putney, J.W.; Steinckwich-Besançon, N.; Numaga-Tomita, T.; Davis, F.M.; Desai, P.N.; D'Agostin, D.M.; Wu, S.; Bird, G.S. The functions of store-operated calcium channels. Biochim. Biophys. Acta Mol. Cell Res. 2017, 1864, 900-906. [CrossRef]

38. Emptage, N.J.; Reid, C.A.; Fine, A. Calcium Stores in Hippocampal Synaptic Boutons Mediate Short-Term Plasticity, Store-Operated $\mathrm{Ca}^{2+}$ Entry, and Spontaneous Transmitter Release. Neuron 2001, 29, 197-208. [CrossRef]

39. Baba, A.; Yasui, T.; Fujisawa, S.; Yamada, R.X.; Yamada, M.K.; Nishiyama, N.; Matsuki, N.; Ikegaya, Y. Activity-Evoked Capacitative $\mathrm{Ca}^{2+}$ Entry: Implications in Synaptic Plasticity. J. Neurosci. 2003, 23, 7737-7741. [CrossRef]

40. Samtleben, S.; Wachter, B.; Blum, R. Store-operated calcium entry compensates fast ER calcium loss in resting hippocampal neurons. Cell Calcium 2015, 58, 147-159. [CrossRef]

41. Klejman, M.E.; Gruszczynska-Biegala, J.; Skibinska-Kijek, A.; Wisniewska, M.B.; Misztal, K.; Blazejczyk, M.; Bojarski, L.; Kuznicki, J. Expression of STIM1 in brain and puncta-like co-localization of STIM1 and ORAI1 upon depletion of $\mathrm{Ca}(2+)$ store in neurons. Neurochem. Int. 2009, 54, 49-55. [CrossRef]

42. Gruszczynska-Biegala, J.; Pomorski, P.; Wisniewska, M.B.; Kuznicki, J. Differential Roles for STIM1 and STIM2 in Store-Operated Calcium Entry in Rat Neurons. PLoS ONE 2011, 6, e19285. [CrossRef]

43. Venkiteswaran, G.; Hasan, G. Intracellular $\mathrm{Ca}^{2+}$ signaling and store-operated $\mathrm{Ca}^{2+}$ entry are required in Drosophila neurons for flight. Proc. Natl. Acad. Sci. USA 2009, 106, 10326-10331. [CrossRef] [PubMed]

44. Skibinska-Kijek, A.; Wisniewska, M.B.; Gruszczynska-Biegala, J.; Methner, A.; Kuznicki, J. Immunolocalization of STIM1 in the mouse brain. Acta Neurobiol. Exp. (Wars). 2009, 69, 413-428.

45. Berna-Erro, A.; Braun, A.; Kraft, R.; Kleinschnitz, C.; Schuhmann, M.K.; Stegner, D.; Wultsch, W.; Eilers, J.; Meuth, S.G.; Stoll, G.; et al. STIM2 Regulates Capacitive $\mathrm{Ca}^{2+}$ Entry in Neurons and Plays a Key Role in Hypoxic Neuronal Cell Death. Sci. Signal. 2009, 2, ra67. [CrossRef] [PubMed]

46. Gruszczynska-Biegala, J.; Kuznicki, J. Native STIM2 and ORAI1 proteins form a calcium-sensitive and thapsigargin-insensitive complex in cortical neurons. J. Neurochem. 2013, 126, 727-738. [CrossRef] [PubMed]

47. Brandman, O.; Liou, J.; Park, W.S.; Meyer, T. STIM2 is a feedback regulator that stabilizes basal cytosolic and endoplasmic reticulum $\mathrm{Ca}^{2+}$ levels. Cell 2007, 131, 1327-1339. [CrossRef]

48. Parvez, S.; Beck, A.; Peinelt, C.; Soboloff, J.; Lis, A.; Monteilh-Zoller, M.; Gill, D.L.; Fleig, A.; Penner, R. STIM2 protein mediates distinct store-dependent and store-independent modes of CRAC channel activation. FASEB J. 2008, 22, 752-761. [CrossRef] [PubMed]

49. Subedi, K.P.; Ong, H.L.; Son, G.Y.; Liu, X.; Ambudkar, I.S. STIM2 Induces Activated Conformation of STIM1 to Control Orai1 Function in ER-PM Junctions. Cell Rep. 2018, 23, 522-534. [CrossRef] [PubMed]

50. Nelson, H.A.; Leech, C.A.; Kopp, R.F.; Roe, M.W. Interplay between ER Ca ${ }^{2+}$ Binding Proteins, STIM1 and STIM2, Is Required for Store-Operated Ca ${ }^{2+}$ Entry. Int. J. Mol. Sci. 2018, 19, 1522. [CrossRef]

51. Moccia, F.; Zuccolo, E.; Soda, T.; Tanzi, F.; Guerra, G.; Mapelli, L.; Lodola, F.; D'Angelo, E. Stim and Orai proteins in neuronal $\mathrm{Ca}^{2+}$ signaling and excitability. Front. Cell. Neurosci. 2015, 9, 153. [CrossRef]

52. Sun, S.; Zhang, H.; Liu, J.; Popugaeva, E.; Xu, N.; Feske, S.; White, C.; Bezprozvanny, I. Reduced Synaptic STIM2 Expression and Impaired Store-Operated Calcium Entry Cause Destabilization of Mature Spines in Mutant Presenilin Mice. Neuron 2014, 82, 79-93. [CrossRef]

53. Somasundaram, A.; Shum, A.K.; McBride, H.J.; Kessler, J.A.; Feske, S.; Miller, R.J.; Prakriya, M. Store-operated CRAC channels regulate gene expression and proliferation in neural progenitor cells. J. Neurosci. 2014, 34, 9107-9123. [CrossRef] 
54. Gopurappilly, R.; Deb, B.K.; Chakraborty, P.; Hasan, G. Stable STIM1 Knockdown in Self-Renewing Human Neural Precursors Promotes Premature Neural Differentiation. Front. Mol. Neurosci. 2018, 11, 178. [CrossRef]

55. Ambudkar, I.S.; de Souza, L.B.; Ong, H.L. TRPC1, Orai1, and STIM1 in SOCE: Friends in tight spaces. Cell Calcium 2017, 63, 33-39. [CrossRef]

56. Wang, Y.; Deng, X.; Mancarella, S.; Hendron, E.; Eguchi, S.; Soboloff, J.; Tang, X.D.; Gill, D.L. The calcium store sensor, STIM1, reciprocally controls Orai and CaV1.2 channels. Science 2010, 330, 105-109. [CrossRef]

57. Park, C.Y.; Shcheglovitov, A.; Dolmetsch, R. The CRAC Channel Activator STIM1 Binds and Inhibits L-Type Voltage-Gated Calcium Channels. Science 2010, 330, 101-105. [CrossRef]

58. Pascual-Caro, C.; Berrocal, M.; Lopez-Guerrero, A.M.; Alvarez-Barrientos, A.; Pozo-Guisado, E.; Gutierrez-Merino, C.; Mata, A.; Martin-Romero, F.J. STIM1 deficiency is linked to Alzheimer's disease and triggers cell death in SH-SY5Y cells by upregulation of L-type voltage-operated $\mathrm{Ca}^{2+}$ entry. J. Mol. Med. 2018, 96, 1061-1079. [CrossRef]

59. Dittmer, P.J.; Wild, A.R.; Dell'Acqua, M.L.; Sather, W.A. STIM1 Ca ${ }^{2+}$ Sensor Control of L-type $\mathrm{Ca}^{2+}$-Channel-Dependent Dendritic Spine Structural Plasticity and Nuclear Signaling. Cell Rep. 2017, 19, 321-334. [CrossRef]

60. Sun, Y.; Zhang, H.; Selvaraj, S.; Sukumaran, P.; Lei, S.; Birnbaumer, L.; Singh, B.B. Inhibition of L-Type Ca ${ }^{2+}$ Channels by TRPC1-STIM1 Complex Is Essential for the Protection of Dopaminergic Neurons. J. Neurosci. 2017, 37, 3364-3377. [CrossRef]

61. Kuang, X.; Liuab, Y.; Changab, Y.; Zhouab, J.; Zhang, H.; Li, Y.; Quab, J.; Wua, S. Inhibition of store-operated calcium entry by sub-lethal levels of proteasome inhibition is associated with STIM1/STIM2 degradation. Cell Calcium 2016, 59, 172-180. [CrossRef]

62. Keil, J.M.; Shen, Z.; Briggs, S.P.; Patrick, G.N. Regulation of STIM1 and SOCE by the Ubiquitin-Proteasome System (UPS). PLoS ONE 2010, 5, e13465. [CrossRef]

63. Ng, A.N.; Krogh, M.; Toresson, H. Dendritic EGFP-STIM1 activation after type I metabotropic glutamate and muscarinic acetylcholine receptor stimulation in hippocampal neuron. J. Neurosci. Res. 2011, 89, 1235-1244. [CrossRef]

64. Gruszczynska-Biegala, J.; Sladowska, M.; Kuznicki, J. AMPA Receptors Are Involved in Store-Operated Calcium Entry and Interact with STIM Proteins in Rat Primary Cortical Neurons. Front. Cell. Neurosci. 2016, 10, 251. [CrossRef]

65. Garcia-Alvarez, G.; Lu, B.; Yap, K.A.F.; Wong, L.C.; Thevathasanm, J.V.; Lim, L.; Ji, F.; Tan, K.W.; Mancuso, J.J.; Tang, W.; et al. STIM2 regulates PKA-dependent phosphorylation and trafficking of AMPARs. Mol. Biol. Cell 2015, 26, 1141-1159. [CrossRef]

66. Yap, K.A.F.; Shetty, M.S.; Garcia-Alvarez, G.; Lu, B.; Alagappan, D.; Oh-Hora, M.; Sajikumar, S.; Fivaz, M. STIM2 regulates AMPA receptor trafficking and plasticity at hippocampal synapses. Neurobiol. Learn. Mem. 2017, 138, 54-61. [CrossRef] [PubMed]

67. Lee, H.K.; Takamiya, K.; He, K.; Song, L.; Huganir, R.L. Specific Roles of AMPA Receptor Subunit GluR1 (GluA1) Phosphorylation Sites in Regulating Synaptic Plasticity in the CA1 Region of Hippocampus. J. Neurophysiol. 2010, 103, 479-489. [CrossRef]

68. Lee, H.K.; Takamiya, K.; Han, J.S.; Man, H.; Kim, C.H.; Rumbaugh, G.; Yu, S.; Ding, L.; He, C.; Petralia, R.S.; et al. Phosphorylation of the AMPA Receptor GluR1 Subunit Is Required for Synaptic Plasticity and Retention of Spatial Memory. Cell 2003, 112, 631-643. [CrossRef]

69. Garcia-Alvarez, G.; Shetty, M.S.; Lu, B.; Yap, K.A.; Oh-Hora, M.; Sajikumar, S.; Bichler, Z.; Fivaz, M. Impaired spatial memory and enhanced long-term potentiation in mice with forebrain-specific ablation of the Stim genes. Front. Behav. Neurosci. 2015, 9, 180. [CrossRef]

70. Ryu, C.; Jang, D.C.; Jung, D.; Kim, Y.G.; Shim, H.G.; Ryu, H.H.; Lee, Y.S.; Linden, D.J.; Worley, P.F.; Kim, S.J. STIM1 Regulates Somatic $\mathrm{Ca}^{2+}$ Signals and Intrinsic Firing Properties of Cerebellar Purkinje Neurons. J. Neurosci. 2017, 37, 8876-8894. [CrossRef]

71. Korkotian, E.; Oni-Biton, E.; Segal, M. The role of the store-operated calcium entry channel Orai1 in cultured rat hippocampal synapse formation and plasticity. J. Physiol. 2017, 595, 125-140. [CrossRef]

72. Korkotian, E.; Frotscher, M.; Segal, M. Synaptopodin regulates spine plasticity: Mediation by calcium stores. J. Neurosci. 2014, 34, 11641-11651. [CrossRef] 
73. Majewski, Ł.; Maciąg, F.; Boguszewski, P.M.; Wasilewska, I.; Wiera, G.; Wójtowicz, T.; Mozrzymas, J.; Kuznicki, J. Overexpression of STIM1 in neurons in mouse brain improves contextual learning and impairs long-term depression. Biochim. Biophys. Acta Mol. Cell Res. 2017, 1864, 1071-1087. [CrossRef]

74. Oliet, S.H.R.; Malenka, R.C.; Nicoll, R.A. Two Distinct Forms of Long-Term Depression Coexist in CA1 Hippocampal Pyramidal Cells. Neuron 1997, 18, 969-982. [CrossRef]

75. Bolshakov, V.Y.; Siegelbaum, S.A. Postsynaptic induction and presynaptic expression of hippocampal long-term depression. Science 1994, 264, 1148-1152. [CrossRef]

76. Khatri, N.; Pareek, V.; Thankur, M.; Kumar, S. Oxidative Stress: Major Threat in Traumatic Brain Injury. CNS Neurol. Disord. Drug Targets 2018, 17, 689-695. [CrossRef]

77. Algattas, H.; Huang, J.H. Traumatic Brain Injury Pathophysiology and Treatments: Early, Intermediate, and Late Phases Post-Injury. Int. J. Mol. Sci. 2014, 15, 309-341. [CrossRef]

78. Weber, J.T. Altered Calcium Signaling Following Traumatic Brain Injury. Front. Pharmacol. 2012, 3, 60. [CrossRef]

79. Weber, J.T.; Rzigalinski, B.A.; Ellis, E.A. Traumatic Injury of Cortical Neurons Causes Changes in Intracellular Calcium Stores and Capacitative Calcium Influx. J. Biol. Chem. 2001, 276, 1800-1807. [CrossRef]

80. Cucchiaroni, M.L.; Viscomi, M.T.; Bernardi, G.; Molinari, M.; Guatteo, E.; Mercuri, N.B. Metabotropic glutamate receptor 1 mediates the electrophysiological and toxic actions of the cycad derivative beta-N-Methylamino-L-alanine on substantia nigra pars compacta DAergic neurons. J. Neurosci. 2010, 30, 5176-5188. [CrossRef]

81. Chen, T.; Fei, F.; Jiang, X.F.; Zhang, L.; Qu, Y.; Huo, K.; Fei, Z. Down-regulation of Homer1b/c attenuates glutamate-mediated excitotoxicity through endoplasmic reticulum and mitochondria pathways in rat cortical neurons. Free Radic Biol. Med. 2012, 52, 208-217. [CrossRef]

82. Hou, P.F.; Liu, Z.H.; Li, N.; Cheng, W.J.; Guo, S.W. Knockdown of STIM1 Improves Neuronal Survival After Traumatic Neuronal Injury Through Regulating mGluR1-Dependent $\mathrm{Ca}^{2+}$ Signaling in Mouse Cortical Neurons. Cell. Mol. Neurobiol. 2015, 35, 283-292. [CrossRef]

83. Fan, X.X.; Hao, Y.Y.; Guo, S.W.; Zhao, X.P.; Xiang, Y.; Feng, F.X.; Liang, G.T.; Dong, Y.W. Knockdown of RTN1-C attenuates traumatic neuronal injury through regulating intracellular $\mathrm{Ca}^{2+}$ homeostasis. Neurochem. Int. 2018, 121, 19-25. [CrossRef]

84. Rao, W.; Zhang, L.; Peng, C.; Hui, H.; Wang, K.; Su, N.; Wang, L.; Dai, S.; Yang, Y.; Chen, T.; et al. Downregulation of STIM2 improves neuronal survival after traumatic brain injury by alleviating calcium overload and mitochondrial dysfunction. Biochim. Biophys. Acta 2015, 1852, 2402-2413. [CrossRef] [PubMed]

85. Das, S.; Tobe, B.; Jain, P.A.; Niles, W.; Winquist, A.; Mastrangelo, L.; Snyder, E.Y. The Application and Future of Neural Stem Cells in Regenerative Medicine. In Translational Regenerative Medicine, 1st ed.; Academic Press: Cambridge, MA, USA, 2015; pp. 403-413.

86. Zipfel, G.J.; Lee, J.M.; Choi, D.W. Reducting calcium overload in the ischemic brain. N. Engl. J. Med. 1999, 341, 1543-1544. [CrossRef]

87. Zhang, M.; Song, J.N.; Wub, Y.; Zhao, Y.L.; Pang, H.G.; Fu, Z.F.; Zhang, B.F.; Ma, X.D. Suppression of STIM1 in the early stage after global ischemia attenuates the injury of delayed neuronal death by inhibiting store-operated calcium entry-induced apoptosis in rats. Neuroreport 2014, 25, 507-513. [CrossRef]

88. Varga-Szabo, D.; Braun, A.; Kleinschnitz, C.; Bender, M.; Pleines, I.; Pham, M.; Renné, T.; Stoll, G.; Nieswandt, B. The calcium sensor STIM1 is an essential mediator of arterial thrombosis and ischemic brain infarction. J. Exp. Med. 2008, 205, 1583-1591. [CrossRef]

89. Chakroborty, S.; Stutzmann, G.E. Calcium channelopathies and Alzheimer's disease: Insight into therapeutic success and failures. Eur. J. Pharmacol. 2014, 739, 83-95. [CrossRef] [PubMed]

90. Busche, M.A.; Konnerth, A. Impairments of neural circuit function in Alzheimer's disease. Philos. Trans. R. Soc. Lond. B Biol. Sci. 2016, 371, 20150429. [CrossRef]

91. Wang, X.; Zhou, X.; Li, G.; Zhang, Y.; Wu, Y.; Song, W. Modifications and Trafficking of APP in the Pathogenesis of Alzheimer's Disease. Front. Mol. Neurosci. 2017, 10, 294. [CrossRef]

92. Secondo, A.; Bagetta, G.; Amantea, D. On the Role of Store-Operated Calcium Entry in Acute and Chronic Neurodegenerative Diseases. Front. Mol. Neurosci. 2018, 11, 87. [CrossRef]

93. Sinnen, B.L.; Bowen, A.B.; Gibson, E.S.; Kennedy, M.J. Local and Use-Dependent Effects of $\beta$-Amyloid Oligomers on NMDA Receptor Function Revealed by Optical Quantal Analysis. J. Neurosci. 2016, 45, 11532-11543. [CrossRef] 
94. Zhang, H.; Wu, L.; Pchitskaya, E.; Zakharova, O.; Saito, T.; Saido, T.; Bezprozvanny, I. Neuronal Store-Operated Calcium Entry and Mushroom Spine Loss in Amyloid Precursor Protein Knock-In Mouse Model of Alzheimer's Disease. J. Neurosci. 2015, 35, 13275-13286. [CrossRef] [PubMed]

95. Gazda, K.; Kuznicki, J.; Wegierski, T. Knockdown of amyloid precursor protein increases calcium levels in the endoplasmic reticulum. Sci. Rep. 2017, 7, 14512. [CrossRef] [PubMed]

96. Lacampagne, A.; Liu, X.; Reiken, S.; Bussiere, S.; Meli, A.C.; Lauritzen, I.; Teich, A.F.; Zalk, R.; Saint, N.; Arancio, O.; et al. Post-translational remodeling of ryanodine receptor induces calcium leak leading to Alzheimer's disease-like pathologies and cognitive deficits. Acta Neuropathol. 2017, 134, 749-767. [CrossRef]

97. Berridge, M.J. Calcium hypothesis of Alzheimer's disease. Pflügers Arch. Eur. J. Physiol. 2010, 459, 441-449. [CrossRef]

98. Briggs, C.A.; Chakroborty, S.; Stutzmann, G.E. Emerging Pathways Driving Early Synaptic Pathology in Alzheimer's Disease. Biochem. Biophys. Res. Commun. 2017, 483, 988-997. [CrossRef]

99. Popugaeva, E.; Pchitskaya, E.; Bezprozvanny, Y. Dysregulation of neuronal calcium homeostasis in Alzheimer's disease-A therapeutic opportunity? Biochem. Biophys. Res. Commun. 2017, 483, 998-1004. [CrossRef]

100. Popugaeva, E.; Pchitskaya, E.; Speshilova, A.; Alexandrov, S.; Zhang, H.; Vlasova, O.; Bezprozvanny, I. STIM2 protects hippocampal mushroom spines from amyloid synaptotoxicity. Mol. Neurodegener. 2015, 10, 37. [CrossRef]

101. Tong, B.C.; Lee, C.S.; Cheng, W.H.; Lai, K.O.; Foskett, J.K.; Cheung, K.H. Familial Alzheimer's disease-associated presenilin 1 mutants promote $\gamma$-secretase cleavage of STIM1 to impair store-operated $\mathrm{Ca}^{2+}$ entry. Sci. Signal 2016, 9, ra89. [CrossRef]

102. Bojarski, L.; Pomorski, P.; Szybinska, A.; Drab, M.; Skibinska-Kijek, A.; Gruszczynska-Biegala, J.; Kuznicki, J. Presenilin-dependent expression of STIM proteins and dysregulation of capacitative $\mathrm{Ca}^{2+}$ entry in familial Alzheimer's disease. Biochim. Biophys. Acta Mol. Cell Res. 2009, 1793, 1050-1057. [CrossRef]

103. Greotti, E.; Capitanio, E.; Wong, A.; Pozzan, T.; Pizzo, P.; Pendin, D. Familial Alzheimer's disease-linked presenilin mutants and intracellular $\mathrm{Ca}^{2+}$ handling: A single-organelle, FRET-based analysis. Cell Calcium 2019, 79, 44-56. [CrossRef]

104. Zhang, H.; Sun, S.; Wu, L.; Pchitskaya, E.; Zakharova, O.; Fon Tacer, K.; Bezprozvanny, I. Store-Operated Calcium Channel Complex in Postsynaptic Spines: A New Therapeutic Target for Alzheimer's Disease Treatment. J. Neurosci. 2016, 36, 11837-11850. [CrossRef] [PubMed]

105. Pchitskaya, E.; Popugaeva, E.; Bezprozvanny, I. Calcium signaling and molecular mechanisms underlying neurodegenerative diseases. Cell Calcium 2018, 70, 87-94. [CrossRef]

106. Wu, J.; Ryskamp, D.A.; Liang, X.; Egorova, P.; Zakharova, O.; Hung, G.; Bezprozvanny, I. Enhanced Store-Operated Calcium Entry Leads to Striatal Synaptic Loss in a Huntington's Disease Mouse Model. J. Neurosci. 2016, 36, 125-141. [CrossRef]

107. Li, S.H.; Li, X.J. Huntingtin-protein interactions and the pathogenesis of Huntington's disease. Trends Genet. 2004, 20, 146-154. [CrossRef] [PubMed]

108. Nopoulos, P.C. Huntington disease: A single-gene degenerative disorder of the striatum. Dialogues Clin. Neurosci. 2016, 18, 91-98. [PubMed]

109. Raymond, L.A. Striatal synaptic dysfunction and altered calcium regulation in Huntington disease. Biochem. Biophys. Res. Commun. 2017, 483, 1051-1062. [CrossRef]

110. Czeredys, M.; Maciag, F.; Methner, A.; Kuznicki, J. Tetrahydrocarbazoles decrease elevated SOCE in medium spiny neurons from transgenic YAC128 mice, a model of Huntington's disease. Biochem. Biophys. Res. Commun. 2017, 483, 1194-1205. [CrossRef]

111. Doria, J.G.; Silva, F.R.; Souza, J.M.; Vieira, L.B.; Carvalho, T.G.; Reis, H.J.; Pereira, G.S.; Dobransky, T.; Ribeiro, F.M. Metabotropic glutamate receptor 5 positive allosteric modulators are neuroprotective in a mouse model of Huntington's disease. Br. J. Pharmacol. 2013, 169, 909-992. [CrossRef]

112. Wu, J.; Ryskamp, D.; Birnbaumer, L.; Bezprozvanny, I. Inhibition of TRPC1-Dependent Store-Operated Calcium Entry Improves Synaptic Stability and Motor Performance in a Mouse Model of Huntington's Disease. J. Huntingt. Dis. 2018, 7, 35-50. [CrossRef]

113. Czeredys, M.; Gruszczynska-Biegala, J.; Schacht, T.; Methner, A.; Kuznicki, J. Expression of genes encoding the calcium signalosome in cellular and transgenic models of Huntington's disease. Front. Mol. Neurosci. 2013, 6, 42. [CrossRef] 
114. Czeredys, M.; Vigont, V.A.; Boeva, V.A.; Mikoshiba, K.; Kaznacheyeva, E.V.; Kuznicki, J. Huntingtin-Associated Protein 1A Regulates Store-Operated Calcium Entry in Medium Spiny Neurons From Transgenic YAC128 Mice, a Model of Huntington's Disease. Front. Cell. Neurosci. 2018, 12, 381. [CrossRef] [PubMed]

115. Vigont, V.A.; Zimina, O.A.; Glushankova, L.N.; Kolobkova, J.A.; Ryazantseva, M.A.; Mozhayeva, G.N.; Kaznacheyeva, E.V. STIM1 Protein Activates Store-Operated Calcium Channels in Cellular Model of Huntington's Disease. Acta Naturae 2014, 6, 40-47.

116. Vigont, V.; Kolobkova, Y.; Skopin, A.; Zimina, O.; Zenin, V.; Glushankova, L.; Kaznacheyeva, E.V. Both Orai1 and TRPC1 are involved in excessive store-operated calcium entry in striatal neurons expressing mutant Huntingtin exon 1. Front. Physiol. 2015, 6, 337. [CrossRef]

117. Wu, J.; Shih, H.P.; Vigont, V.; Hrdlicka, L.; Diggins, L.; Singh, C.; Mahoney, M.; Chesworth, R.; Shapiro, G.; Zimina, O.; et al. Neuronal store-operated calcium entry pathway as a novel therapeutic target for Huntington's disease treatment. Chem. Biol. 2011, 18, 777-793. [CrossRef]

(C) 2019 by the authors. Licensee MDPI, Basel, Switzerland. This article is an open access article distributed under the terms and conditions of the Creative Commons Attribution (CC BY) license (http://creativecommons.org/licenses/by/4.0/). 